\title{
Rapid and accurate point-of-care testing for SARS-CoV2 antibodies
}

4 Sally Esmail ${ }^{1}$, Michael J. Knauer ${ }^{2}$, Husam Abdoh ${ }^{2}$, Benjamin Chin-Yee ${ }^{3}$, Peter Stogios ${ }^{5}$,

5 Almagul Seitova ${ }^{4}$, Ashley Hutchinson ${ }^{4}$, Farhad Yusifov ${ }^{4}$, Tatiana Skarina ${ }^{5}$, Elena

6 Evdokimova $^{5}$, Suzanne Ackloo ${ }^{4}$, Lori Lowes ${ }^{2}$, Courtney Voss ${ }^{1}$, Benjamin D. Hedley ${ }^{2}$, Vipin

7 Bhayana ${ }^{2}$, Ian Chin-Yee ${ }^{2}$ and Shawn S-C. Li ${ }^{1 *}$

$9{ }^{1}$ Departments of Biochemistry, Schulich School of Medicine and Dentistry, Western 10 University, London, Ontario N6G 2V4, Canada;

$11{ }^{2}$ Department of Pathology and Laboratory Medicine and ${ }^{3}$ Divison of Hematology, Western

12 University and London Health Sciences Centre, 800 Commissioners Rd E, London, Ontario

13 N6A 5W9, Canada;

$14{ }^{4}$ Structural Genomics Consortium, University of Toronto, 101 College St, MaRS South

15 Tower, Suite 700, Toronto, Ontario M5G 1L7, Canada;

$16{ }^{5}$ Department of Chemical Engineering and Applied Chemistry, University of Toronto, 200

17 College St., Toronto, Ontario M5S 3E5, Canada. 


\section{ABSTRACT}

25

26 The COVID-19 pandemic, caused by the severe acute respiratory syndrome coronavirus-2

27 (SARS-CoV-2), has grown into worst public health crisis since the 1918 influenza pandemic.

28 As COVID-19 continues to spread around the world, there is urgent need for a rapid, yet accurate antibody test to identify infected individuals in populations to inform health decisions. We have developed a rapid, accurate and cost-effective serologic test based on antibody-dependent agglutination of antigen-coated latex particles, which uses $\sim 5 \mu$ plasma and takes $<5 \mathrm{~min}$ to complete with no instrument required. The simplicity of this test makes it ideal for point-of-care (POC) use at the community level. When validated using plasma samples that are positive or negative for SARS-CoV-2, the agglutination assay detected antibodies against the receptor-binding domain of the spike (S-RBD) or the nucleocapsid (N) protein of SARS-CoV-2 with 100\% specificity and $29 \%$ sensitivity. Furthermore, we found that the strength of the S-RBD antibody response measured by the agglutination assay correlated with the efficiency of the plasma in blocking RBD binding to the angiotensin converting enzyme 2 (ACE2) in a surrogate neutralization assay, suggesting that the agglutination assay may be used to identify individuals with virus-neutralizing antibodies. Intriguingly, we found that $>92 \%$ of patients had detectable antibodies on the day of positive viral RNA test, suggesting that seroconversion may occur earlier than previously thought and that the agglutination antibody test may complement RNA testing for POC diagnosis of SARS-CoV-2 infection. 
Development of rapid point-of-care COVID-19 diagnostics for use at the community level remains a top priority in the global response to the COVID-19 pandemic ${ }^{1}$. While capacity for detecting SARS-CoV-2 based on nucleic acid amplification (NAAT) has grown immensely and enabled effective public health responses, serologic testing for virus specific antibodies has not gained the same widespread application, due to concerns over sensitivity, specificity, cost and turn-around time ${ }^{1,2}$. Although NAAT is the current gold standard for diagnosing acute infection, it is not effective in identifying individuals who have recovered from previous infection ${ }^{3}$. Given that approximately $40 \%$ of infected individuals remain asymptomatic $^{1,4,5}$, large-scale antibody testing could help better establish the true extent of the COVID-19 pandemic, identifying disease hotspots and high-risk populations to enable more effective isolation and contact tracing ${ }^{1,3,6}$. Moreover, antibody testing may identify individuals with a strong neutralizing antibody response who may be suitable donors for convalescent plasma/serum therapy for the treatment of those with severe symptoms ${ }^{7}$.

To date, a number of antibody tests have been approved for emergency use in the US and Europe. These tests detect the IgG, IgM or IgA antibody against the spike (including the receptor binding domain, RBD) or nucleocapsid $(\mathrm{N})$ protein of the SARS-CoV-2 virus by enzyme-linked immunosorbent assay (ELISA) ${ }^{3}$. ELISA-based antibody tests, which can be qualitative or quantitative, require specialized instruments and are usually performed in a lab by a trained technician. The sensitivity and specificity of different ELISA kits vary widely ${ }^{8-10}$. To enable point-of-care (POC) testing, several rapid diagnostic tests (RDTs) based on lateral flow have been developed. Although the RDTs reduced the time of the antibody test to 10-30 minutes from 2-5 hours (for ELISA), they generally suffer from decreased sensitivity and specificity compared to ELISA-based assays ${ }^{1,11-13}$.

To address the pressing need for a simple, rapid, yet accurate antibody test ${ }^{1}$, we resorted to the tested-and-proven serology method of agglutination that has been used in blood typing and antibody testing ${ }^{14-16}$. We show here that the agglutination of red blood cells (RBCs) or latex particles induced by specific antigen-antibody interaction affords a highly sensitive and accurate assay for SARS-CoV-2 antibodies. We validated the antibody assay based on latex 
79 NAAT, 121 samples that were NAAT negative and 100 SARS-CoV-2 naïve plasma samples.

80 The agglutination-based antibody assay produced 100\% specificity and 97-98.2\% sensitivity.

81 Because this simple assay requires no instrument and generates results in 2 minutes, it has the 82 potential to be used as a POC or at-home test.

\section{RESULTS}

\section{Agglutination-based serologic testing for SARS-CoV-2 antibodies}

Agglutination of RBCs is widely used in blood typing whereas latex particle agglutination assays have been used to detect antibodies against a variety of different viruses. We sought to establish whether either or both approaches could be adapted for SARS-CoV-2 antibody testing. In principle, coating the RBCs or the latex particles with a SARS-CoV-2 specific antigen would enable their respective agglutination by the corresponding antibody (Fig. 1). To explore this notion, we labelled Group O (R2R2) RBCs carrying the D antigen with the spike RBD (S-RBD) or the RNA binding domain of the nucleocapsid (N-RBD) protein through streptavidin-biotin mediated coupling (Figs. S1 \& S2, see Materials and Methods for details). Incubating the antigen-coated RBCs with COVID $-19^{+}$plasma led to robust agglutination whereas the COVID-19- plasma failed to induce RBC agglutination, suggesting that the aggregation of the S-RBD/N-RBD-coated RBCs may be used to detect antibody response to SARS-CoV-2 (Fig. S2).

To develop a cost-effective agglutination assay, we next investigated if latex particles were a suitable substitute for the RBCs. To this end, we coated latex particles with recombinant S-RBD or the full-length nucleocapsid (N) protein (Fig. S1). The antigen coated latex beads were first tested with a monoclonal anti-S-RBD and a polyclonal anti-nucleocapsid antibody. Upon incubating with the corresponding antibody, the antigen-coated latex particles formed clumps within two minutes. Importantly, the area of clump formation grew larger with increasing antibody concentrations (Fig. S3). Although latex agglutination was commonly used as a qualitative assay, it is possible to determine the degree of agglutination based on the area of clump formation via image analysis. As shown in Fig. 2, the percentage of

110 agglutination for both the S-RBD- and N-coated latex particles increased when an 111 incremental amount of anti-S-RBD or anti-N antibody was added. Fitting the data to Hill's 
112 equation yielded Hill's coefficient of 1.7 for the former and 1.8 for the latter. This suggests

113 that the antibody-induced agglutination of latex particles is a cooperative event (Fig. 2A\&B).

115 We next examined if the latex agglutination assay could be used to gauge COVID-19

116 antibody response. Using plasma samples from patients tested positive for SARS-CoV-2 by

117 NAAT and confirmed for strong antibody response by ELISA, we found that the patient

118 plasma samples were not only capable of inducing agglutination of the S-RBD- or N-coated

119 latex particles, they did so in a concentration-dependent manner. As shown in Fig. 2C\&D, the

120 extent of agglutination decreased as the plasma was diluted, indicating that the agglutination

121 assay may be used to estimate antibody titer as in an ELISA-based antibody test.

The latex agglutination-based antibody assay showed high sensitivity and specificity

To validate the antibody test based on latex particle agglutination, we carried out agglutination assays for 290 residual plasma samples from individuals that were tested positive (169) or negative (121) for virus RNA by the Roche cobas SARS-CoV-2 test ${ }^{9}$. To assess specificity, we also included 100 virus-naïve samples banked in 2018 in our agglutination assay. None of the 121 SARS-CoV-2- or the 100 Pre-COVID-19 plasma samples was capable of promoting the agglutination of either the S-RBD- or N-coated latex particles, indicating $100 \%$ specificity for the agglutination assay (Table 1). In contrast, of the 169 SARS-CoV-2 ${ }^{+}$plasma samples tested, 166 (98.2\%) promoted agglutination in response to the S-RBD antigen and $164(97 \%)$ to the $\mathrm{N}$ antigen, with overall sensitivity of $98.2 \%$. We compared the latex agglutination assay with the Euroimmune IgG test for the S antibody and the Roche Elecsys ${ }^{\circledR}$ Total assay for the $\mathrm{N}$ antibody using the same set of SARS-CoV-2 ${ }^{+}$ plasma samples and found that the latex agglutination assay outperformed both ELISA-based antibody tests (Table 2). The agglutination assay also exhibited better specificity than either ELISA kit (Table 2). Quantification of the agglutination data showed that the COVID-19 group is significantly different from the COVID-19- or pre-COVID-19 group, indicating that the latex agglutination assay effectively distinguished SARS-CoV2 ${ }^{+}$from SARS-CoV2individuals (Fig. 3A\&B).

143 Based on the background signals of the COVID-19- samples (0-4\% agglutination for both 144 S-RBD- and N-coated latex particles), we set 5\% agglutination as the cut-off for antibody 145 positivity. To facilitate the use of the latex agglutination assay as a simple, semi-quantitative 
146 antibody test, we developed a numerical scoring system for antibody response. We assigned

147 the scores $1,2,3$ and 4 to samples that produced $5-25 \%, 25-50 \%, 50-75 \%$ and $>75 \%$ 148 agglutination, respectively (Fig. S4). We found that this scoring scheme effectively 149 distinguished samples with strong antibody response from those with medium or weak ones 150 (Fig. 3C\&D). The agglutination score may be readily assigned by visual inspection and 151 comparing to reference wells containing a predetermined amount of pure anti-S-RBD or 152 anti-N antibody (Fig. S3).

The S-RBD antibody response correlated with neutralizing antibody titer

Because neutralizing antibodies $(\mathrm{Nab})$ play a pivotal role in the humoral immune response to the virus ${ }^{17}$, we next examined if the S-RBD antibody response determined by the agglutination assay correlated with neutralization efficiency. We developed a surrogate neutralization assay by measuring the efficacy of patient plasma in blocking S-RBD binding to its host receptor, angiotensin converting enzyme 2 (ACE2) in vitro. Similar approaches have been used by others to evaluate neutralization efficiency of patient plasma or therapeutic antibodies $^{18,19}$. Briefly, binding of biotinylated ACE2 to immobilized S-RBD is detected by ELISA through HRP-conjugated streptavidin. The presence of neutralizing antibody would block this interaction, resulting in reduction of the ELISA signal. Using this surrogate neutralization assay, we found that the neutralization efficiency increased with the agglutination score for the S-RBD antibody (Fig. 4A). Intriguingly, comparison of samples with distinct $\mathrm{S}-\mathrm{RBD}$ and $\mathrm{N}$ antibody responses indicated that the neutralization efficiency was significantly correlated with the S-RBD, but not the $\mathrm{N}$ antibody strength. This is not surprising given that the nucleocapsid is not involved in mediating virus entry into the host cells via ACE2. Nevertheless, it remains to be determined if the plasma with strong $\mathrm{N}$ antibody response would confer immunity by inhibiting virus replication in vivo.

The agglutination assay allowed for early antibody detection and tracking of dynamic antibody response

We noted that the agglutination assay detected antibody response in $>92 \%$ plasma samples collected on the day of SARS-CoV2 ${ }^{+}$diagnosis by NAAT and in $100 \%$ samples on day 2 and afterward. This is in stark contrast to the $47 \%$ to $83 \%$ sensitivity for ELISA-based antibody tests on samples collected within 7 days of positive NAAT ${ }^{9}$. The superb sensitivity of the 
180 latex agglutination assay suggests that it may be used to detect antibody response in the early 181 stage of virus infection and monitor its dynamic changes over time ${ }^{12,20,21}$. Using serial blood samples from SARS-CoV-2 $2^{+}$patients, we compared the changes in the S-RBD and $\mathrm{N}$ antibody responses between days 1 and day 3 (Fig. 4C\&D). We found that the majority of patients showed detectable S-RBD and/or $\mathrm{N}$ antibodies on $\mathrm{NAAT}^{+}$day 1 . Moreover, the antibody titer increased significantly on day 3 compared to day 1 . Because it is not possible to determine how long these patients had contracted the virus prior to the NAAT test, seroconversion might have occurred for some on the day of diagnosis. Nevertheless, we were able to detect anti-S-RBD or anti-N antibodies on day 3 for several patients who showed no detectable antibody on day 1 , suggesting seroconversion occurred rapidly in these patients ${ }^{4}$. Taken together, these data suggest that the latex agglutination assay may be used to diagnose active infection in conjunction with NAAT. Combined antibody and RNA testing may increase the sensitivity of the later. Moreover, the agglutination-based antibody test may be used to monitor the evolvement of humoral immune reaction in infected individuals over time.

\section{DISCUSSION}

Antibody testing offers an additional and much needed tool for managing the COVID-19 pandemic, which may allow for rapid and cost-effective POC diagnosis to facilitate treatment and public health responses. Furthermore, antibody testing may play an important role in identifying individuals who have gained protective immunity from previous exposure or immunization programs. While the clinical trial results for several vaccine candidates are encouraging, seroconversion is unlikely to occur for all vaccinated individuals ${ }^{22}$. A highly sensitive and specific antibody test would allow for accurate assessment of humoral response to a vaccine, and serial testing post-vaccination could indicate the duration of humoral immunity against SARS-CoV-2. Such information will be invaluable to inform public health decisions, both for directing resource allocation and determining response to vaccination.

209 While most serology tests used in the clinic are specific for a specific antibody isoform, $\operatorname{IgG}$,

$210 \operatorname{IgM}$ or $\operatorname{IgA}$, the latex agglutination antibody assay is, in principle, isotope-independent ${ }^{11}$.

211 This may contribute to its high sensitivity, especially on samples collected in the early phase

212 of infection when $\operatorname{IgG}$ isotope switching has not yet occurred. It has been shown that the $\operatorname{IgM}$ 213 antibody response proceeds that of $\mathrm{IgG}^{3,11}$, and the pentameric architecture of $\operatorname{IgM}$ may make 
214 it a stronger promoter of agglutination than IgG. Moreover, the agglutination assay detects 215 antibodies against the spike (S) and the nucleocapsid $(\mathrm{N})$ in parallel whereas most existing 216 assays are specific for either protein. These factors explain why the agglutination assay could 217 detect antibody in $>92 \%$ plasma samples collected on the day of NAAT $^{+}$diagnosis and $100 \%$ 218 on day 2 and onwards whereas other antibody tests were less sensitive. The ability of our 219 assay to detect antibodies at the early stages of infection suggests that it may be used to 220 complement or confirm the diagnosis based on NAAT, which is prone to false positives or false negatives especially when done only once ${ }^{23}$.

Several features of the agglutination assay make it an ideal candidate for POC or at-home antibody testing. First, the assay is highly sensitive and accurate, with $100 \%$ specificity and COVID-19 patients on the day of diagnosis. This sensitivity rivals that of NAAT tests ${ }^{23}$. Second, the agglutination test is fast. It takes two minutes from mixing the plasma with the latex particles to getting the result. Third, the agglutination assay is simple to run and instrument-free. As the formation of latex bead clumps is easy to identify by the naked eye, the test may be performed without extensive specialized training. Fourth, because the agglutination assay takes only $\sim 5 \mu$ plasma, it may be developed into a finger prick blood test suitable for at-home use. Finally, the low cost of the latex agglutination assay makes it universally affordable and ideal for antibody testing at the community or population level, in high- and low-resource settings alike.

\section{ACKNOWLEDGEMENT}

238 We thank the Center for Structural Genomics of Infectious Diseases (CDGID) for the N-RBD 239 expression plasmid, Dr. Jason McLellan for expression plasmid for human ACE2, Dr. Shane

240 Harding for the spike-receptor binding domain expression construct, and Yanjun Li for 241 technical assistance. This work was supported by a grant (to SSCL, ICY, MK, BCY and VB)

242 from the Ontario Research Fund-COVID-19 Rapid Research Fund and by the Toronto 243 COVID-19 Action Fund. SE was supported by a Post-Doctoral Fellowship from the National 244 Science and Engineering Council of Canada. SSCL held a Canada Research Chair in 245 Molecular and Epigenetic Basis of Cancer. 
medRxiv preprint doi: https://doi.org/10.1101/2020.11.30.20241208; this version posted December 2, 2020. The copyright holder for this preprint (which was not certified by peer review) is the author/funder, who has granted medRxiv a license to display the preprint in perpetuity.

All rights reserved. No reuse allowed without permission.

247 Table 1: Clinical performance of the agglutination-based antibody assay

248

\begin{tabular}{|c|c|c|c|c|c|c|}
\hline \multirow[t]{2}{*}{ Samples } & \multicolumn{2}{|c|}{$\begin{array}{l}\text { Anti-S-RBD } \\
\text { (n) }\end{array}$} & \multicolumn{2}{|c|}{$\begin{array}{l}\text { Anti-N } \\
\text { (n) }\end{array}$} & \multirow[t]{2}{*}{$\begin{array}{c}\text { Overall } \\
\text { Sensitivity }\end{array}$} & \multirow[t]{2}{*}{$\begin{array}{l}\text { Overall } \\
\text { Specificity }\end{array}$} \\
\hline & Positive & Negative & Positive & Negative & & \\
\hline $\begin{array}{l}\text { SARS-CoV-2 NAAT } \\
\text { positive }(n=169)\end{array}$ & 166 & 3 & 164 & 5 & $\begin{array}{c}\mathbf{9 8 . 2 \%} \\
(166 / 169)\end{array}$ & \\
\hline \multicolumn{7}{|l|}{$\begin{array}{c}\text { Days of SARS-CoV-2 } \\
\text { NAAT positive }\end{array}$} \\
\hline $\begin{array}{c}1 \\
(n=41)\end{array}$ & 38 & 3 & 36 & 5 & $\begin{array}{l}92.7 \% \\
(38 / 41)\end{array}$ & \\
\hline $\begin{array}{c}2 \\
(n=31)\end{array}$ & 30 & 1 & 31 & 0 & $100 \%$ & \\
\hline $\begin{array}{c}\geq 3 \\
(n=97)\end{array}$ & 97 & 0 & 96 & 1 & $100 \%$ & \\
\hline $\begin{array}{c}\text { SARS-CoV-2 NAAT } \\
\text { negative } \\
(n=121)\end{array}$ & 0 & 121 & 0 & 121 & & $100 \%$ \\
\hline $\begin{array}{l}\text { Pre-COVID-19 } \\
\quad(n=100)\end{array}$ & 0 & 100 & 0 & 100 & & $100 \%$ \\
\hline
\end{tabular}


medRxiv preprint doi: https://doi.org/10.1101/2020.11.30.20241208; this version posted December 2, 2020. The copyright holder for this preprint (which was not certified by peer review) is the author/funder, who has granted medRxiv a license to display the preprint in perpetuity.

All rights reserved. No reuse allowed without permission.

\section{Table 2: Comparison in sensitivity and specificity between the agglutination-based}

251 and ELISA-based antibody assays

252

\begin{tabular}{|c|c|c|c|c|c|c|c|c|}
\hline \multirow[t]{2}{*}{ Anti-S (RBD) } & \multicolumn{2}{|c|}{$\begin{array}{l}\text { Agglutination assay } \\
\text { (n) }\end{array}$} & \multicolumn{2}{|c|}{$\begin{array}{c}\text { ELISA }^{9} \\
\text { EUROIMMUNE } \\
\text { (n) }\end{array}$} & \multirow[t]{2}{*}{$\begin{array}{l}\text { Sensitivity } \\
\text { (Agglutination) }\end{array}$} & \multirow[t]{2}{*}{$\begin{array}{l}\text { Sensitivity } \\
\text { (Euroimmune) }\end{array}$} & \multirow[t]{2}{*}{$\begin{array}{c}\text { Specificity } \\
\text { (Agglutination) }\end{array}$} & \multirow[t]{2}{*}{$\begin{array}{l}\text { Specificity } \\
\text { (Euroimmune) }\end{array}$} \\
\hline & Positive & Negative & Positive & Negative & & & & \\
\hline $\begin{array}{c}\text { SARS-CoV-2 NAAT } \\
\text { positive }(n=121)\end{array}$ & 118 & 3 & 90 & 31 & $\begin{array}{c}\mathbf{9 7 . 5 \%} \\
(118 / 121)\end{array}$ & $\begin{array}{c}74.4 \% \\
(90 / 121)\end{array}$ & & \\
\hline $\begin{array}{c}\text { SARS-CoV-2 NAAT } \\
\text { Negative \& } \\
\text { preCOVID-19 }\end{array}$ & 0 & 221 & 11 & 194 & \multicolumn{2}{|c|}{ NA } & $\begin{array}{c}100 \% \\
(221 / 221)\end{array}$ & $\begin{array}{c}\mathbf{9 4 . 6 \%} \\
(194 / 205)\end{array}$ \\
\hline \multirow[t]{2}{*}{ Anti-N } & \multicolumn{2}{|c|}{$\begin{array}{l}\text { Agglutination assay } \\
\text { (n) }\end{array}$} & \multicolumn{2}{|c|}{$\begin{array}{c}\text { ELISA }^{9} \\
\text { Roche Elecsys } ® \\
\text { (n) }\end{array}$} & $\begin{array}{c}\text { Sensitivity } \\
\text { (Agglutination) }\end{array}$ & $\begin{array}{c}\text { Sensitivity } \\
\text { (Roche) }\end{array}$ & $\begin{array}{c}\text { Specificity } \\
\text { (Agglutination) }\end{array}$ & $\begin{array}{c}\text { Specificity } \\
\text { (Roche) }\end{array}$ \\
\hline & Positive & Negative & Positive & Negative & & & & \\
\hline $\begin{array}{c}\text { SARS-CoV-2 NAAT } \\
\text { positive }(n=69)\end{array}$ & 68 & 1 & 66 & 2 & $\begin{array}{l}\mathbf{9 8 . 6 \%} \\
(68 / 69)\end{array}$ & $\begin{array}{l}95.7 \% \\
(66 / 69)\end{array}$ & & \\
\hline $\begin{array}{c}\text { SARS-CoV-2 NAAT } \\
\text { Negative \& } \\
\text { preCOVID-19 }\end{array}$ & 0 & 221 & 1 & 135 & & & $\begin{array}{c}100 \% \\
(221 / 221)\end{array}$ & $\begin{array}{c}\mathbf{9 9 \%} \\
(135 / 136)\end{array}$ \\
\hline
\end{tabular}

253

254

255

256 
FIGURE LEGENDS

Figure 1. Illustration of the principle of agglutination assay for SARS-CoV-2 antibody

testing. (A) Latex particles or red blood cells (RBCs) are surface-coated with a SARS-CoV-2 antigen, the S-RBD or nucleocapsid $(\mathrm{N})$. Incubation with plasma containing antibodies against the coated antigen would induce agglutination of the latex particles or RBCs. (B) A representative image of the agglutination assay using latex beads coated with S-RBD.

Figure 2. Antibody-induced latex particle agglutination correlates with the antibody titer.

(A, B) Changes in agglutination in response to increased concentrations of the anti-S-RBD $(n=3)$ or anti-N antibody $(n=3)$. Dash lines represent fitted curves to Hill equation (h, Hill

(D) antibody-induced agglutination decreased with increased dilution of plasma. Shown are agglutination data (in $\log 2$ scale) from three COVID- $19^{+}$plasma samples with 1:2 to 1:128 dilution (three replicates/concentration).

Figure 3. Agglutination assay distinguished COVID-19 ${ }^{+}$from COVID-19 ${ }^{-}$samples. COVID-19- $(\mathrm{n}=121)$ and Pre-COVID-19 $(\mathrm{n}=100)$ samples determined by the aggregation assay. (C, D) The strength of the S-RBD and $\mathrm{N}$ antibody response in the COVID-19 ${ }^{+}(\mathrm{n}=169)$ plasma samples could be determined semi-quantitatively by the aggregation score (1-4 denotes weak-to-strong antibody response). Statistical analyses were performed using unpaired Student's t-test with Welch's correction ( $\mathrm{p}$ values shown on graph).

Figure 4. Using the latex agglutination assay to determine neutralizing antibody titer and dynamic changes in antibody response. (A) Neutralization antibody response correlated significantly with the agglutination score. $\mathrm{P}$ values calculated based on unpaired Student t-test ( $\mathrm{n}=10$ for each group).

(B) Spearman (r) correlation of efficiency of neutralization and S-RBD or $\mathrm{N}$ antibody response $(\mathrm{n}=25)$. (C, D) Dynamic changes in 
medRxiv preprint doi: https://doi.org/10.1101/2020.11.30.20241208; this version posted December 2, 2020. The copyright holder for this preprint (which was not certified by peer review) is the author/funder, who has granted medRxiv a license to display the preprint in perpetuity.

All rights reserved. No reuse allowed without permission.

286 antibody responses in COVID-19 patients. $\mathrm{n}=20$ for day 1 and $\mathrm{n}=20$ for day 3 ; $\mathrm{p}$-values

287 calculated based on unpaired Student's t-test with Welch's correction.

MATERIALS AND METHODS

\section{Blood sample collection}

290 Blood samples were collected following a protocol (study number: 116284) approved by the

291 Research Ethics Board (REB) of Western University. The plasma samples were de-identified

292 prior to transfer from the Laboratory of Clinical Medicine (London Health Sciences Center, 293 London, Canada) to a biosafety Level 3 (CL3) lab (ImPaKT, Western University) following 294 Transportation of Dangerous Goods (TDG) guidelines. All plasma samples were 295 heat-inactivated at $56{ }^{\circ} \mathrm{C}$ for 30 minutes at the ImPaKT CL3 facility as per Western university 296 biosafety regulation. Heat inactivated plasma samples were then transferred to the testing 297 laboratory. We tested the effect of heat inactivation on SARS-CoV-2 antibody titer and found 298 no significant impact of heat-inactivation (see also Fig. S5).

\section{Recombinant protein production and purification}

300 The expression plasmid for human ACE2 cloned into the mammalian expression vector $\mathrm{p} \alpha \mathrm{H}$ 301 (residues 1-615 with a C-terminal HRV3C protease cleavage site, a TwinStrepTag and an 302 8XHisTag) was a generous gift by Dr. McLellan. SARS-CoV-2 S-RBD cloned into pCAGGs 303 the expression vector was received from Dr. Harding's lab. SARS-CoV-2 N-RBD was cloned 304 into the pMCSG53 prokaryotic expression vector (residues 47-173-terminal 6x-His tag + TEV 305 protease cleavage site). Recombinant ACE2 and S-RBD proteins were produced by transient transfection of Expi293F cells (ThermoFisher Scientific, A14527) with a corresponding expression vectors and

309 FectoPRO ${ }^{\circledR}$ DNA transfection reagent (Polyplus-transfection ${ }^{\circledR}$ SA, Cat. \#116-010).

310 Supernatants from transfected cells were harvested after 96 hours of the post-transfection time 311 by centrifugation of the culture at 65,000 RPM for 30 min at $4^{\circ} \mathrm{C}$. Cleared supernatant was then 312 incubated with $4 \mathrm{ml}$ TALON ${ }^{\circledR}$ Metal Affinity Resin (Takara Bio USA, Inc. Cat\#635652) for 2h 313 at $4^{0} \mathrm{C}$. Ni-NTA chromatography was used to purify His-tagged recombinant proteins. Each 314 protein was dialyzed and concentrated in Amicon centrifugal units (EMD Millipore) in a final 
medRxiv preprint doi: https://doi.org/10.1101/2020.11.30.20241208; this version posted December 2, 2020. The copyright holder for this preprint (which was not certified by peer review) is the author/funder, who has granted medRxiv a license to display the preprint in perpetuity.

All rights reserved. No reuse allowed without permission.

buffer of 20mM HEPES (pH 7.5, 200mM NaCl, pH 7.5, 5\% glycerol).

317 Recombinant N-RBD was expressed in E. coli BL21(DE3)-Gold. Ni-NTA chromatography 318 and size exclusion chromatography-Superdex S200 was used to purify N-RBD. The tag was 319 cleaved using TEV followed by dialysis. The N-RBD protein was resuspended in $0.1 \mathrm{M} \mathrm{NaCl}$, $32020 \mathrm{mM}$ HEPES pH 7.5 and stored at $-80{ }^{\circ} \mathrm{C}$ until use. Recombinant nucleocapsid (residues 321 1-419) was obtained from RayBiotech (Cat \#230-01104). Protein purity was confirmed by 322 SDS-PAGE (Fig. S1).

\section{Preparation of SARS-CoV-2 antigen coated latex particles}

324 Blue dyed polystyrene latex beads, $0.8 \mu \mathrm{m}$ in diameter, were purchased from Sigma Aldrich 325 (L1398). Prior to use, the latex beads were washed according to the manufacturer's 326 instructions with some modifications. Briefly, $2.5 \mathrm{~mL}$ of $5 \%(\mathrm{w} / \mathrm{v})$ latex suspension was 327 washed twice in $10 \mathrm{~mL}$ PBS buffer (135 mM NaCl, $2.6 \mathrm{mM} \mathrm{KCl}, 8 \mathrm{mM} \mathrm{Na} 2 \mathrm{HPO}_{4}$, and 1.5 $328 \mathrm{mM} \mathrm{KH}_{2} \mathrm{PO}_{4}, \mathrm{pH} 7.4$ ) by mixing and centrifuging the latex suspension at 3,000g for 10 329 minutes at room temperature. The beads were then resuspended with $2.5 \mathrm{ml} 0.025 \mathrm{M}$ MES 330 buffer (2-(N-Morpholino) ethanesulfonic acid, $\mathrm{pH} 6.0)$ to obtain 5\% (w/v) suspension.

SARS-CoV-2 antigen-latex particle conjugates were prepared by passive adsorption following the procedures described by Mahat et $\mathrm{al}^{24}$, with some modifications. Briefly, 0.4 $\mathrm{mL}$ of $5 \%(\mathrm{w} / \mathrm{v})$ latex suspension was centrifuged at 3,000 $\mathrm{g}$ for 5 minutes at room temperature, and the supernatant was discarded. The beads were incubated with $200 \mu \mathrm{g}$ recombinant Receptor Binding Domain of the SARS-CoV-2 spike protein (S-RBD)

337 (Structural Genomics Consortium, University of Toronto) or the Nucleocapsid protein (N 338 protein) (RayBiotech, 230-01104) in $4 \mathrm{~mL}$ MES buffer. The mixture was allowed to incubate 339 for 24 hours at $4{ }^{\circ} \mathrm{C}$ with periodic mixing. After conjugation, the antigen-latex bead conjugate 340 was centrifuged, and the supernatant was kept for determination of unabsorbed protein 341 concentration (Bio-Rad protein assay kit). The antigen-bead conjugate was washed twice 342 with PBS and blocked for $30 \mathrm{~min}$ at room temperature in PBS containing 3\% bovine serum 343 albumin (BSA). The conjugate was then resuspended at 2.5\% (w/v) in PBS containing $1 \%$ 344 BSA and stored at $4{ }^{\circ} \mathrm{C}$ until use. 
348 For the agglutination assay, $5 \mu \mathrm{l}$ plasma was mixed with $25 \mu \mathrm{l}$ antigen-coated beads $(2.5 \%$, $349 \mathrm{w} / \mathrm{v})$ per assay. The agglutination was allowed to proceed for $2 \mathrm{~min}$ at room temperature 350 before imaging with a camera. The relative degree of agglutination induced by the 351 SARS-CoV-2 antibody was measured by the area of clump formation based on the 352 corresponding image. Agglutination data analyses were performed using qualitative and semi-quantitative assessments. For semi-quantification of agglutination, the image analysis software Qupath (v0.1.2) was used (https://qupath.github.io/) and quantification was done by calculating the percentage of agglutination based on estimated agglutination/clumps area $\left(\mathrm{mm}^{2}\right)$ relative to the total latex reaction area. In qualitative assessments, agglutination intensity was inspected visually, and agglutination score was assigned (i.e. 1, 2, 3 and 4). Specifically, 1 corresponds to small clumps with $\sim 25 \%$ agglutination, 2 ( $\sim 50 \%$ agglutination), 3 ( $\sim 75 \%$ agglutination), and 4 (large clumps that forms in less than 1 min with $\sim 100 \%$ agglutination). Based on data from the COVID-19 negative samples (including NAAT negative and samples collected in 2018), the cut-off for positivity was set to 5\% of agglutination.

Preparation of red blood cells conjugated with SARS-CoV-2 antigen

364 The recombinant spike receptor-binding domain (S-RBD) or the nucleocapsid RNA-binding domain (N-RBD) was conjugated in 30-fold molar excess biotin using EZ-Link Sulfo-NHS-LC-LC-Biotin (Thermo Scientific, A35358). Excess unbound biotin was removed using ZebaTM Spin Desalting Columns, 7KMWCO (Thermo Scientific, 89890). Anti-D-IgG was purified from Immucor Anti-D Series 4 (IgG \& IgM monoclonal blend) by using protein A magnetic affinity purification (G8782, Promega). The purified anti-D-IgG was then concentrated $(3 \mathrm{mg} / \mathrm{ml})$ and stored at $4{ }^{\circ} \mathrm{C}$ until use. Anti-D was then conjugated with streptavidin according to manufacturer instruction (ab102921, abcam).

373 Bioconjugation of Anti-D-IgG-streptavidin with Reagent Red Blood Cells (RRBC) [0.8\% 374 R2R2; blood group O; Rh/D-antigen+] (Ortho-Clinical Diagnostics SELECTOGEN, 375 6902315) was done by incubating the anti-D-IgG-streptavidin with RRBC for 30 min at room 376 temperature. The RRBC-anti-D-streptavidin complex was then washed twice with low ionic strength RBC diluent (MTSTM Diluent 2 PLUS; Micro Typing Inc., MTS9330S). The 
medRxiv preprint doi: https://doi.org/10.1101/2020.11.30.20241208; this version posted December 2, 2020. The copyright holder for this preprint (which was not certified by peer review) is the author/funder, who has granted medRxiv a license to display the preprint in perpetuity.

All rights reserved. No reuse allowed without permission.

379 was then resuspended in the same RBC diluent. RBC-anti-D-IgG-streptavidin was then 380 conjugated with either biotin-S-RBD or biotin-N-RBD for $15 \mathrm{~min}$ at room temperature. The 381 RRBC-anti-D-sterptaviding-biotin-S-RBD/N-RBD was stored at $4{ }^{\circ} \mathrm{C}$ until use. The RRBC 382 agglutination assay was carried out in the same way as for latex agglutination described 383 above.

\section{S-RBD-ACE2 binding ELISA and surrogate neutralization assay}

386

ELISA plate Coating and blocking -S-RBD was dissolved $(5 \mu \mathrm{g} / \mathrm{ml})$ in Tris buffer saline (TBS) (20 mM Tris, $150 \mathrm{mM} \mathrm{NaCl}, \mathrm{pH} 7.4$ ) and $100 \mu \mathrm{l}$ of the S-RBD solution was added to each well of an ELISA plate and incubate at $4{ }^{\circ} \mathrm{C}$ overnight with slow shaking. The antigen-coated wells were washed 3 times with TBS-tween (TBST) (20 mM Tris, $150 \mathrm{mM} \mathrm{NaCl}, 0.1 \%$ Tween 20). The S-RBD coated wells were blocked by $100 \mu \mathrm{l}$ of the ChonBlock ${ }^{\mathrm{TM}}$ blocking/sample dilution ELISA buffer (Chondrex, Inc., 9068) for 1 hour at room temperature with slow shaking followed washing 3 times with TBST.

ACE2:S-RBD binding assay- ACE2 was biotinylated as described above. Biotin-ACE2 $(1 \mu \mathrm{g} / \mathrm{m})$ was added to S-RBD-coated plate after blocking and incubated for 1 hour at room temperature. The wells were washed 3 times with TBST to remove unbound biotin-ACE2. Streptavidin-HRP (1000-fold dilution with Chonblock blocking buffer) was then added to each well and incubated for 1 hour at room temperature. The wells were washed 3 times with TBST and TMB substrate (3,3',5,5'-Tetramethylbenzidine, Thermo Scientific, N301) was added for reaction development and $0.18 \mathrm{M} \mathrm{H} 2 \mathrm{SO} 4$ was used to stop reaction. Absorbance at 450nm was measured to detect the S-RBD bound ACE2. S-RBD-coated wells (blocked) for 1 hour at room temperature. The wells were washed three times with TBST. Biotin-ACE2 was then added to the wells and incubated for 1 hour at room temperature followed by washing, reaction development and detection as described above.

\section{Statistical analysis}

408

All statistical analyses were done using the GraphPad Prism9 software. Specifically, the Hill coefficient (h) was calculated from fitting agglutination data obtained using anti-S-RBD and

411 anti-N antibodies to the Hill equation. COVID- $19^{+}$samples with distinct agglutination scores 
medRxiv preprint doi: https://doi.org/10.1101/2020.11.30.20241208; this version posted December 2, 2020. The copyright holder for this preprint

(which was not certified by peer review) is the author/funder, who has granted medRxiv a license to display the preprint in perpetuity.

All rights reserved. No reuse allowed without permission.

412 and COVID-19- ${ }^{-}$samples were analyzed using unpaired t-test with Welch's correction (no

413 assumption of equal SD between two groups). Changes in agglutination for samples before

414 and after heat-inactivation were analyzed by paired t-test. Spearman's correlation rank was

415 done to study correlation between antibody titter and ACE2:S-RBD neutralization efficiency.

416

417 


\section{REFERENCE}

419

4201 Peeling, R. W. et al. Serology testing in the COVID-19 pandemic response. The

421 Lancet Infectious Diseases 20, e245-e249, doi:10.1016/s1473-3099(20)30517-x

$422 \quad(2020)$.

4232 Kruttgen, A. et al. Comparison of four new commercial serologic assays for

424 determination of SARS-CoV-2 IgG. J Clin Virol 128, 104394,

425 doi:10.1016/j.jcv.2020.104394 (2020).

4263 Ravi, N., Cortade, D. L., Ng, E. \& Wang, S. X. Diagnostics for SARS-CoV-2

427 detection: A comprehensive review of the FDA-EUA COVID-19 testing landscape.

$428 \quad$ Biosens Bioelectron 165, 112454, doi:10.1016/j.bios.2020.112454 (2020).

4294 Amanat, F. et al. A serological assay to detect SARS-CoV-2 seroconversion in

430 humans. Nat Med 26, 1033-1036, doi:10.1038/s41591-020-0913-5 (2020).

4315 He X, L. E., Wu P et al. Temporal dynamics in viral shedding and transmissibility of 432 COVID-19. Nat Med 26, 672-675 (2020).

4336 Weisberg, S. P. et al. Distinct antibody responses to SARS-CoV-2 in children and 434 adults across the COVID-19 clinical spectrum. Nat Immunol, 435 doi:10.1038/s41590-020-00826-9 (2020).

4367 Shen, C. et al. Treatment of 5 Critically Ill Patients With COVID-19 With

437 Convalescent Plasma. JAMA 323, 1582-1589, doi:10.1001/jama.2020.4783 (2020).

4388 Jaaskelainen, A. J. et al. Performance of six SARS-CoV-2 immunoassays in

439 comparison with microneutralisation. J Clin Virol 129, 104512,

$440 \quad$ doi:10.1016/j.jcv.2020.104512 (2020).

4419 Knauer, M. J. et al. Interim analysis of the clinical performance of five SARS-Cov-2

442 serology assays. Clin Biochem, doi:10.1016/j.clinbiochem.2020.09.002 (2020).

$44310 \quad$ Lisboa Bastos, M. et al. Diagnostic accuracy of serological tests for covid-19:

444 systematic review and meta-analysis. BMJ 370, m2516, doi:10.1136/bmj.m2516

$445 \quad$ (2020).

44611 Pavlova, I. P., Nair, S. S., Kyprianou, N. \& Tewari, A. K. The Rapid Coronavirus 
Antibody Test: Can We Improve Accuracy? Front Med (Lausanne) 7, 569, doi:10.3389/fmed.2020.00569(2020).

44912 Whitman, J. D. et al. Test performance evaluation of SARS-CoV-2 serological assays.

$450 \quad$ medRxiv, doi:10.1101/2020.04.25.20074856 (2020).

$451 \quad 13$ Li, Z. et al. Development and clinical application of a rapid IgM-IgG combined antibody test for SARS-CoV-2 infection diagnosis. J Med Virol, doi:10.1002/jmv.25727 (2020).

45414 Gupta, A. \& Chaudhary, V. K. Whole-blood agglutination assay for on-site detection

of human immunodeficiency virus infection. J Clin Microbiol 41, 2814-2821, doi:10.1128/jcm.41.7.2814-2821.2003 (2003).

45715 Hursh DA, A. A., Sun R, Iltis JP, Rice DH and Gleaves CA. Evaluation of a Latex Particle Agglutination Assay for the Detection of Cytomegalovirus Antibody in Patient Serum. J. Clin. Microbiol, 2878-2879 (1989).

$46016 \quad$ Alves, D. et al. Rapid Gel Card Agglutination Assays for Serological Analysis Following SARS-CoV-2 Infection in Humans. ACS Sens 5, 2596-2603, doi:10.1021/acssensors.0c01050 (2020).

46317 Jiang, S., Hillyer, C. \& Du, L. Neutralizing Antibodies against SARS-CoV-2 and Other Human Coronaviruses. Trends Immunol 41, 355-359, doi:10.1016/j.it.2020.03.007 (2020).

46618 Tortorici MA, B. M., Lempp FA, Pinto D, Dang HV, Rosen LE, McCallum M, Bowen J, Minola A, Jaconi S, Zatta F, De Marco A, Guarino B, Bianchi S, Lauron EJ, Tucker H, Zhou J, Peter A, Havenar-Daughton C, Wojcechowskyj JA, Case JB, Chen RE, Sprugasci N, Culap K, Benigni F, Abdelnabi R, Foo SC, Schmid MA, Cameroni E, Riva A, Gabrieli A, Galli M, Pizzuto MS, Neyts J, Diamond MS, Virgin HW, Snell G, 
medRxiv preprint doi: https://doi.org/10.1101/2020.11.30.20241208; this version posted December 2, 2020. The copyright holder for this preprint (which was not certified by peer review) is the author/funder, who has granted medRxiv a license to display the preprint in perpetuity.

All rights reserved. No reuse allowed without permission.

47519 Abe, K. T. et al. A simple protein-based surrogate neutralization assay for

476 SARS-CoV-2. JCI Insight 5, doi:10.1172/jci.insight.142362 (2020).

47720 Robbiani, D. F. et al. Convergent Antibody Responses to SARS-CoV-2 Infection in

478 Convalescent Individuals. bioRxiv, doi:10.1101/2020.05.13.092619 (2020).

47921 Qu, J. et al. Profile of IgG and IgM antibodies against severe acute respiratory

$480 \quad$ syndrome coronavirus 2 (SARS-CoV-2). Clin Infect Dis, doi:10.1093/cid/ciaa489

$481 \quad(2020)$.

48222 Thanh Le, T. et al. The COVID-19 vaccine development landscape. Nat Rev Drug

483 Discov 19, 305-306, doi:10.1038/d41573-020-00073-5 (2020).

48423 Jarrom, D. et al. Effectiveness of tests to detect the presence of SARS-CoV-2 virus, 485 and antibodies to SARS-CoV-2, to inform COVID-19 diagnosis: a rapid systematic 486 review. BMJ Evid Based Med, doi:10.1136/bmjebm-2020-111511 (2020).

48724 Mahat, M., Abdullah, W. Z. \& Che Hussin, C. M. Conventional rapid latex 488 agglutination in estimation of von Willebrand factor: method revisited and potential 489 clinical applications. Journal of immunology research 2014 (2014).

490

491 
A

o
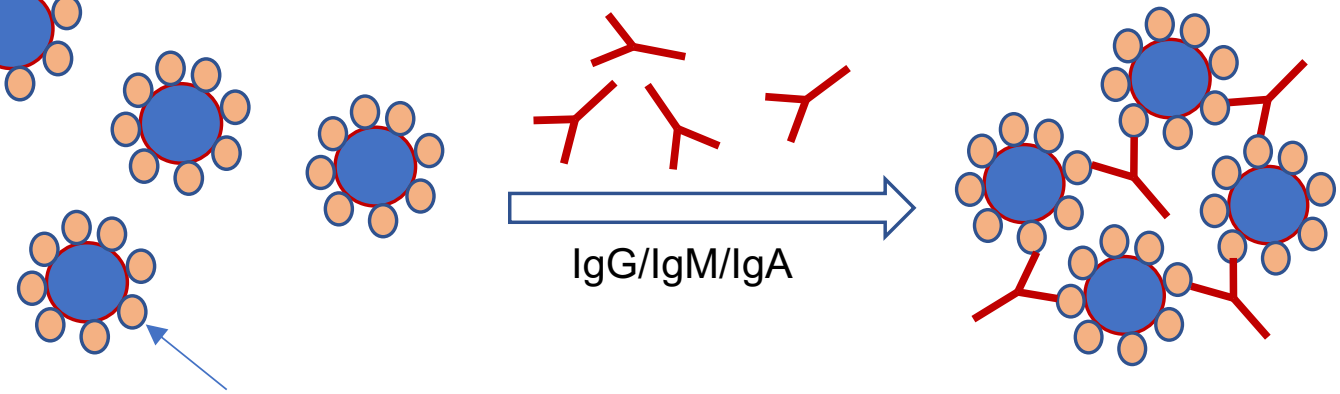

S-RBD

Nucleocapsid

Antibody-mediated agglutination

B

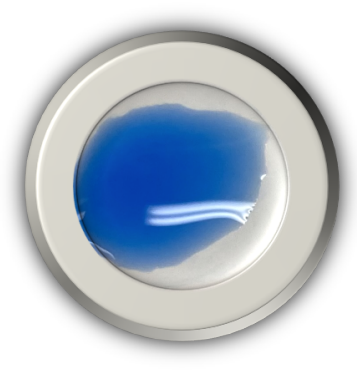

COVID-19+

\section{Plasma}

Figure 1: Illustration of the principle of agglutination assay for SARS-CoV-2 antibody testing. (A) Latex particles or red blood cells(RBC) are surface-coated with a SARS-CoV-2 antigen, the S-RBD or nucleocapsid (N). Incubation with plasma containing antibodies against the coated antigen would induce agglutination of the latex particles or RBCs. (B) A representative image of the agglutination assay using latex beads coated with S-RBD. 
Esmail et al.

A

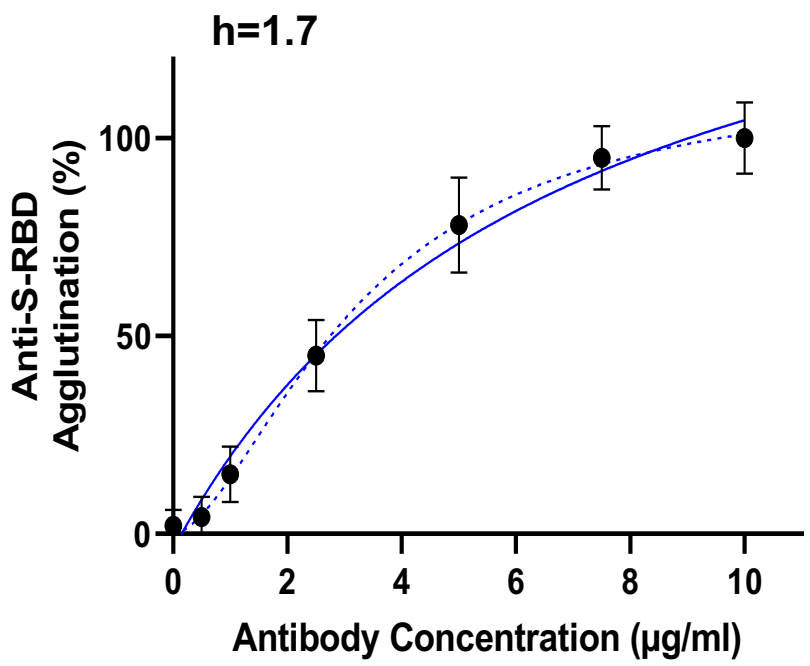

C

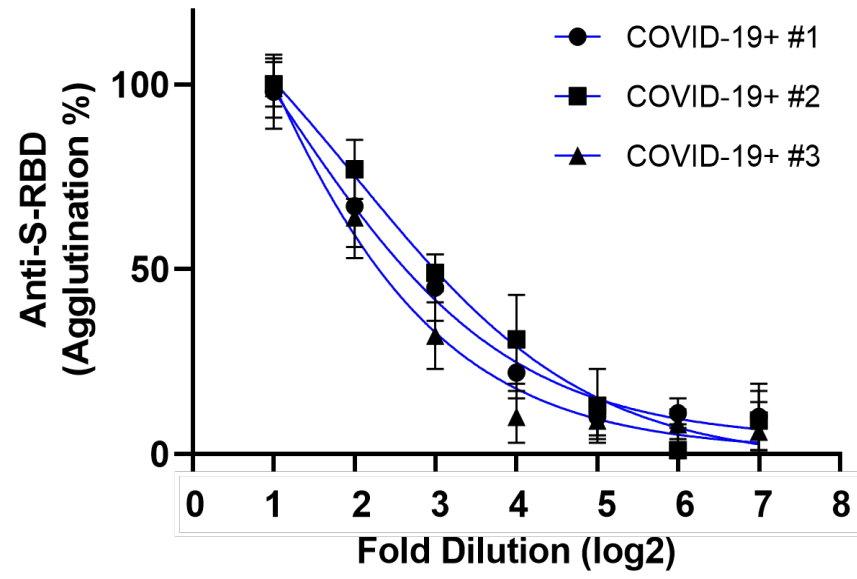

B

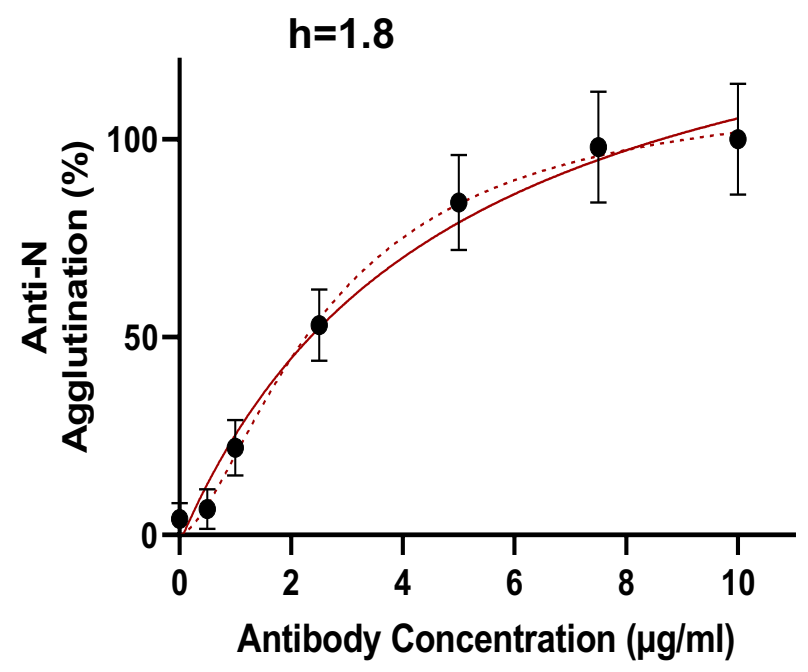

D

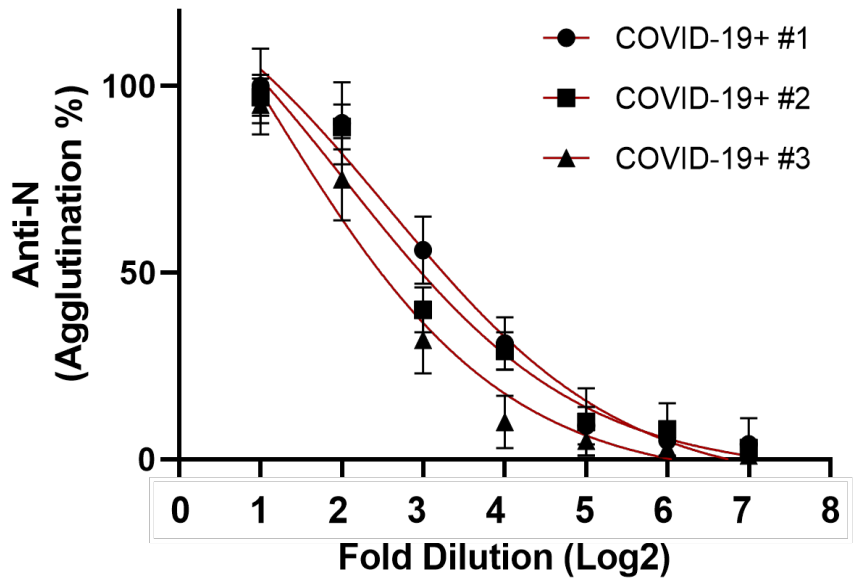

Figure 2. Antibody-induced latex particle agglutination correlates with the antibody titer. (A, B) Changes in agglutination in response to increased concentrations of the anti-SRBD $(n=3)$ or anti-N antibody $(n=3)$. Dash lines represent fitted curves to Hill equation ( $h$, Hill coefficient). (C, D) S-RBD (C) or N (D) antibody-induced agglutination decreased with increased dilution of plasma. Shown are agglutination data (in log2 scale) from three COVID$19^{+}$plasma samples with $1: 2$ to $1: 128$ dilution. Data shown are from three replicates per concentration. 
Esmail et al.

A

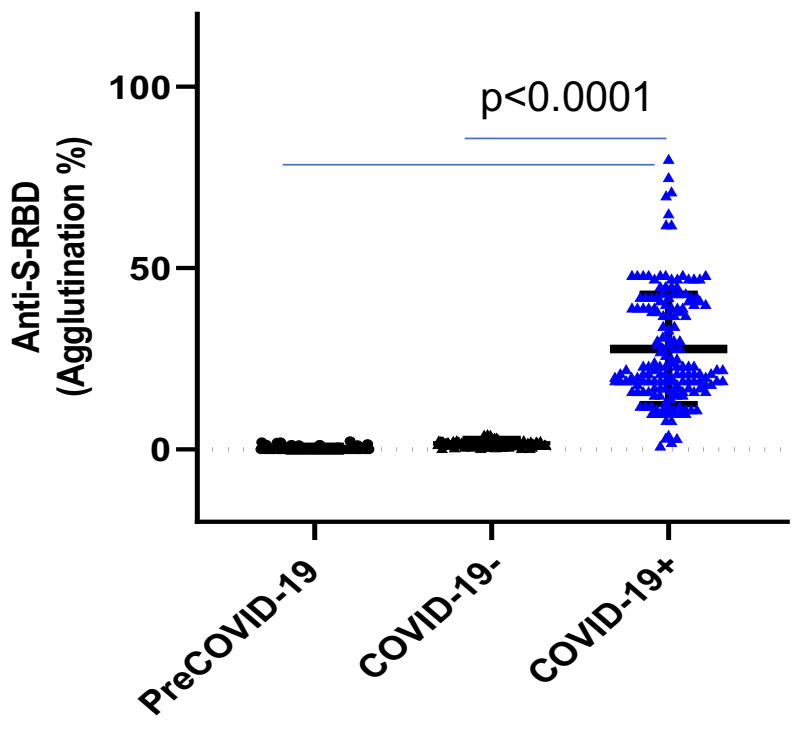

C

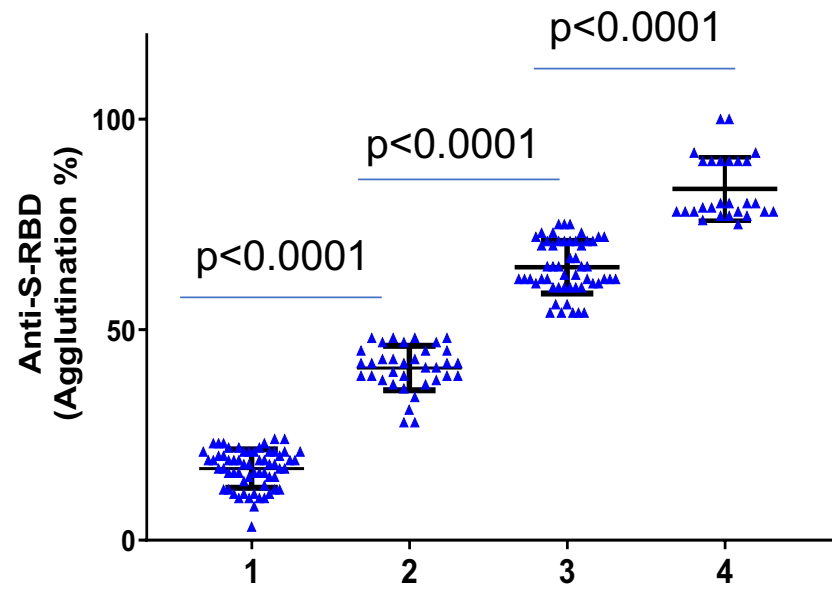

Agglutination Score (aS-RBD)

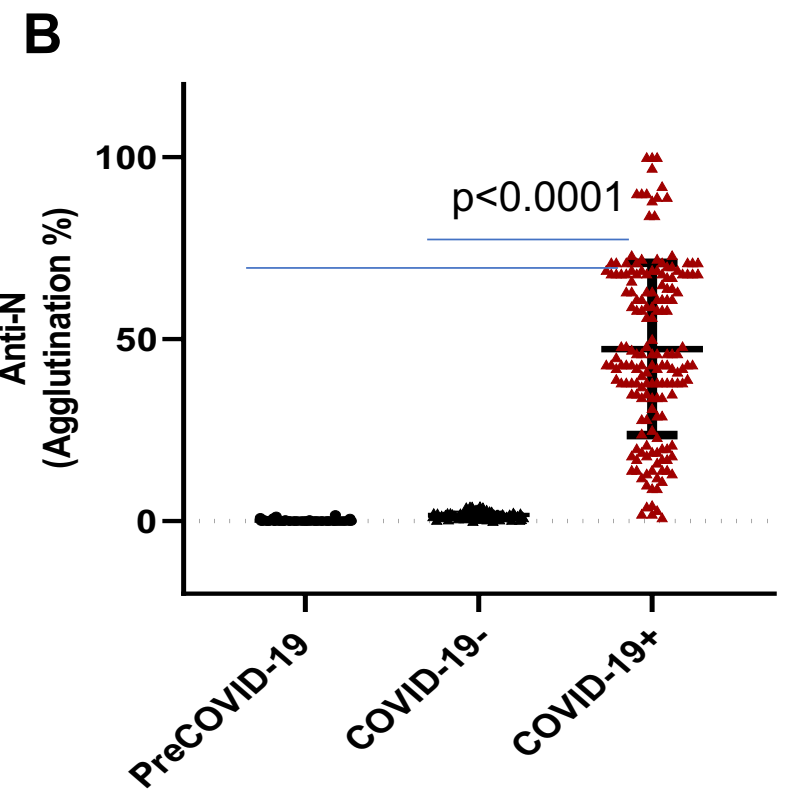

D

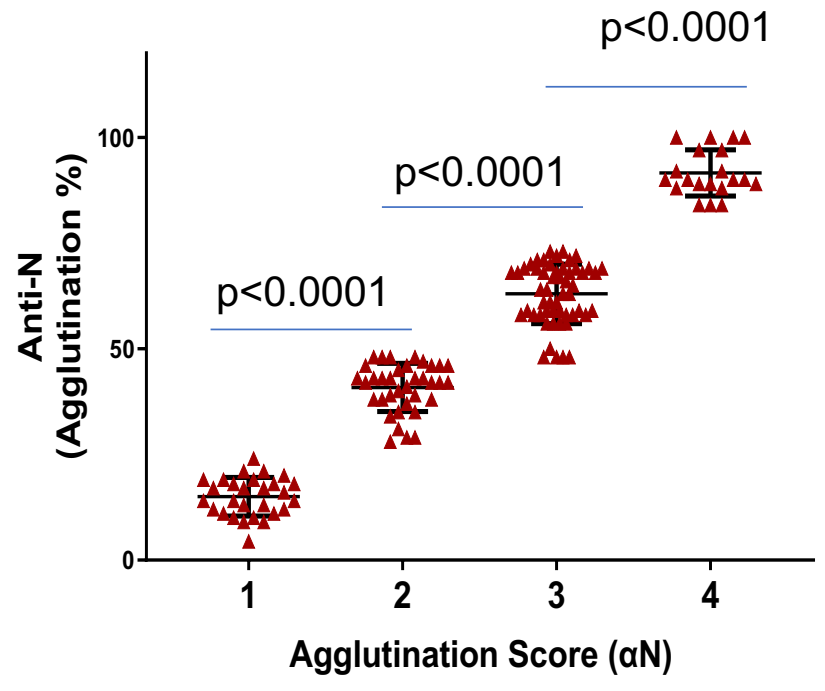

Figure 3. Agglutination assay distinguished COVID-19+ from COVID-19- samples. (A, B) Comparison of S-RBD (A) and $\mathrm{N}$ antibody responses between COVID-19+ ( $n=169)$, COVID-19- $(n=121)$ and Pre-COVID-19 $(n=100)$ samples determined by the aggregation assay. (C, D) The strength of the S-RBD and $\mathrm{N}$ antibody response in the COVID-19+ $(n=169)$ plasma samples could be determined semi-quantitatively by the aggregation score (1-4 denotes weak-to-strong antibody response). Statistical analyses were performed using unpaired Student's t-test with Welch's correction ( $p$ values shown on graph). 
Esmail et al.

A
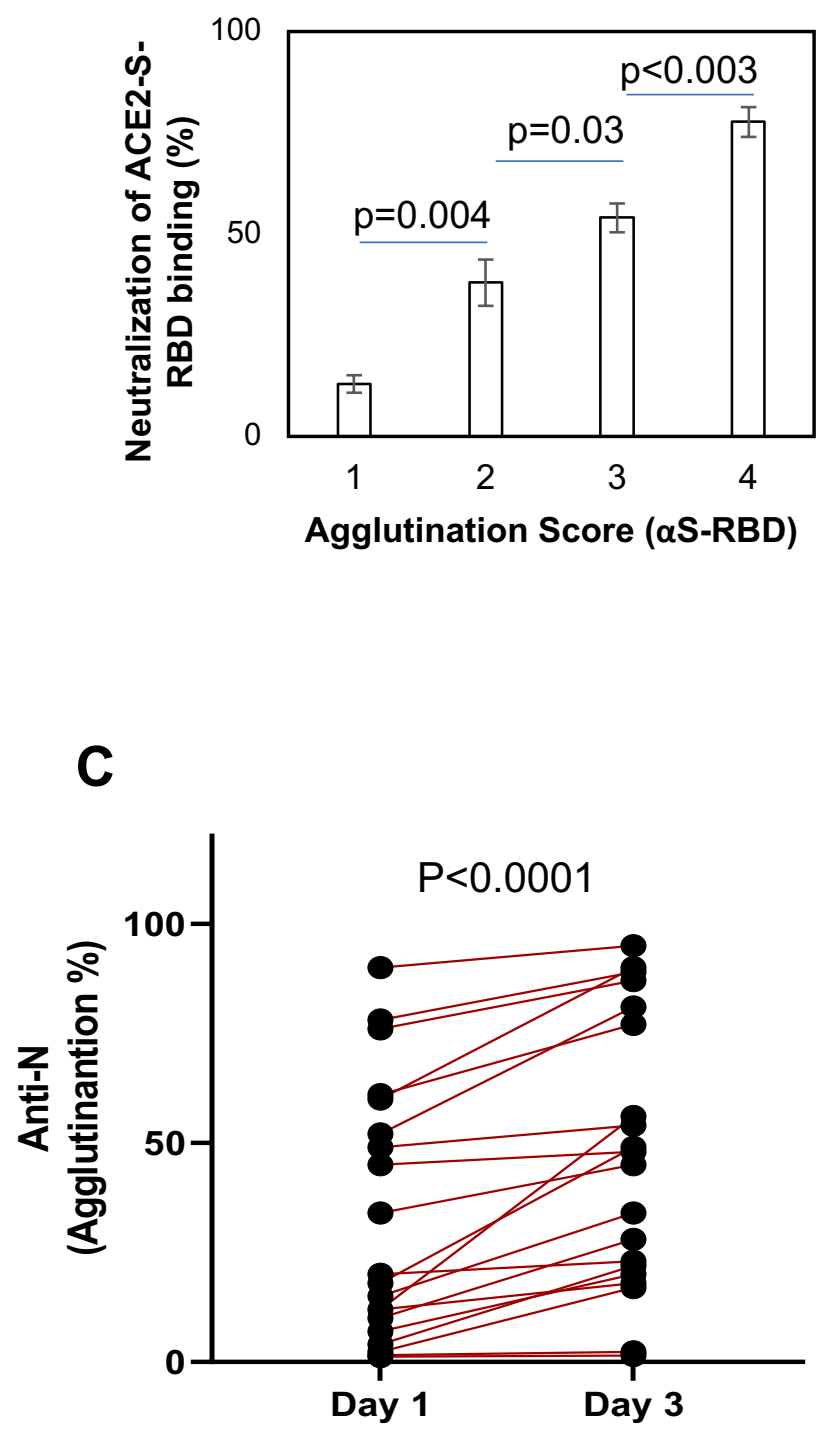

B

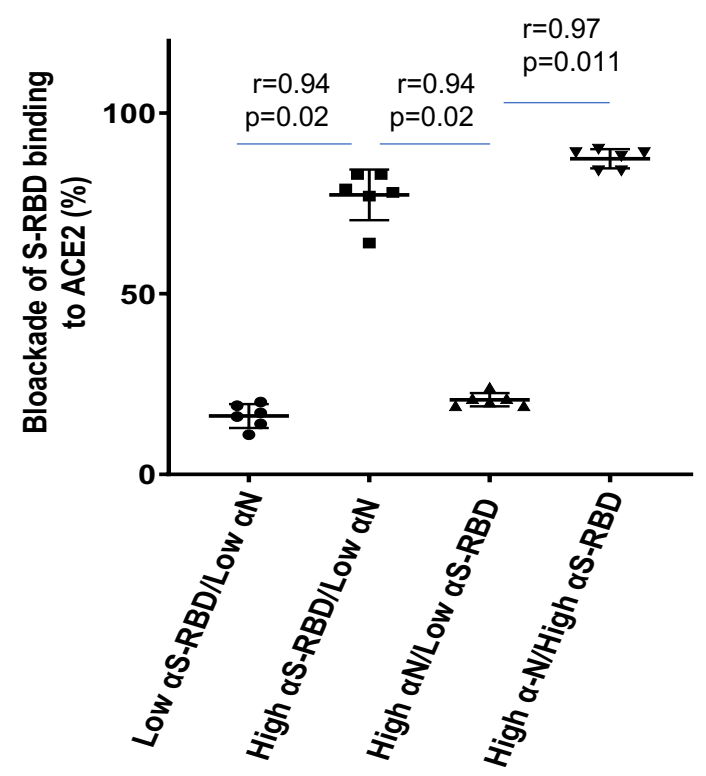

D

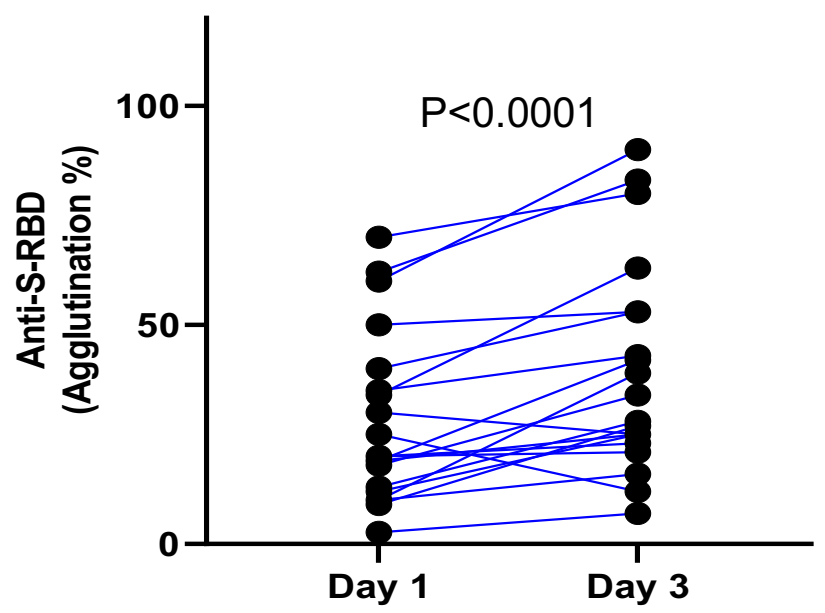

Figure 4. Using the latex agglutination assay to determine neutralizing antibody titer and dynamic changes in antibody response. (A) Neutralization antibody response correlated significantly with the agglutination score. $\mathrm{P}$ values calculated based on unpaired Student t-test ( $\mathrm{n}=10$ for each group). (B) Spearman ( $r$ ) correlation of efficiency of neutralization and S-RBD or $\mathrm{N}$ antibody response $(n=25)$. (C, D) Dynamic changes in antibody responses in COVID-19 patients. $n=20$ for day 1 and $n=20$ for day 3; $p$-values calculated based on unpaired Student's t-test with Welch's correction. 


\section{Supplementary Figures}

\section{Rapid and accurate point-of-care testing for SARS-CoV2 antibodies}

Sally Esmail ${ }^{1}$, Michael J. Knauer², Husam Abdoh², Benjamin Chin-Yee ${ }^{3}$, Peter

Stogios ${ }^{5}$, Almagul Seitova ${ }^{4}$, Ashley Hutchinson ${ }^{4}$, Farhad Yusifov ${ }^{4}$, Tatiana Skarina ${ }^{5}$, Elena Evdokimova ${ }^{5}$, Suzanne Ackloo ${ }^{4}$, Lori Lowes², Courtney Voss ${ }^{1}$, Benjamin D. Hedley²$^{2}$, Vipin Bhayana², Ian Chin-Yee ${ }^{2}$ and Shawn S-C. Li ${ }^{1 *}$

${ }^{1}$ Departments of Biochemistry, Schulich School of Medicine and Dentistry, Western University, London, Ontario N6G 2V4, Canada;

${ }^{2}$ Department of Pathology and Laboratory Medicine and ${ }^{3}$ Divison of Hematology, Western University and London Health Sciences Centre, 800 Commissioners Rd E, London, Ontario N6A 5W9, Canada;

${ }^{4}$ Structural Genomics Consortium, University of Toronto, 101 College St, MaRS South Tower, Suite 700, Toronto, Ontario M5G 1L7, Canada;

${ }^{5}$ Department of Chemical Engineering and Applied Chemistry, University of Toronto, 200 College St., Toronto, Ontario M5S 3E5, Canada.

*Corresponding author: sli@uwo.ca 
medRxiv preprint doi: https://doi.org/10.1101/2020.11.30.20241208; this version posted December 2, 2020. The copyright holder for this preprint (which was not certified by peer review) is the author/funder, who has granted medRxiv a license to display the preprint in perpetuity. All rights reserved. No reuse allowed without permission.

\section{Esmail et al.}

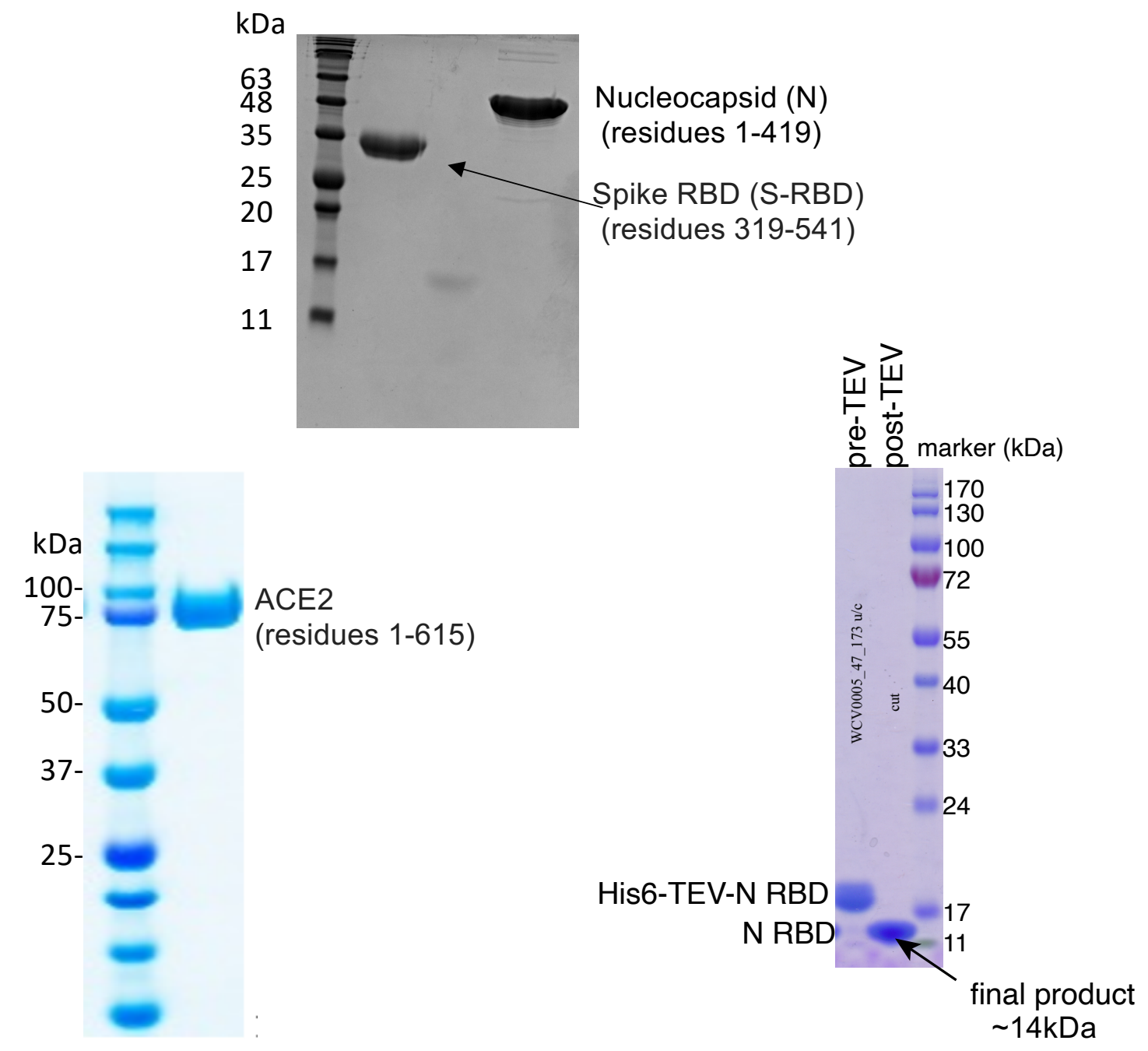

Figure S1. SDS-PAGE images of recombinant SARS-CoV-2 proteins employed in the current study. 


\section{Esmail et al.}

A

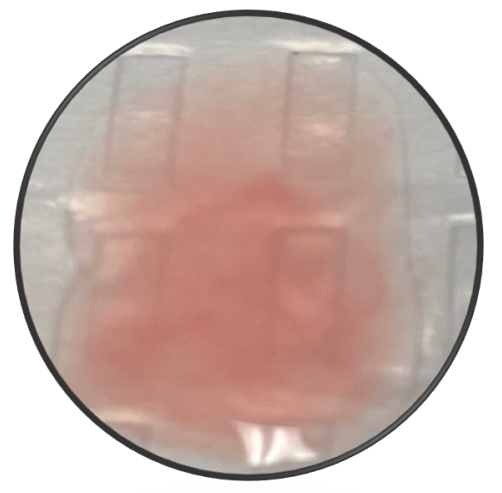

S-RBD-RBC

SARS-CoV2- plasma

B

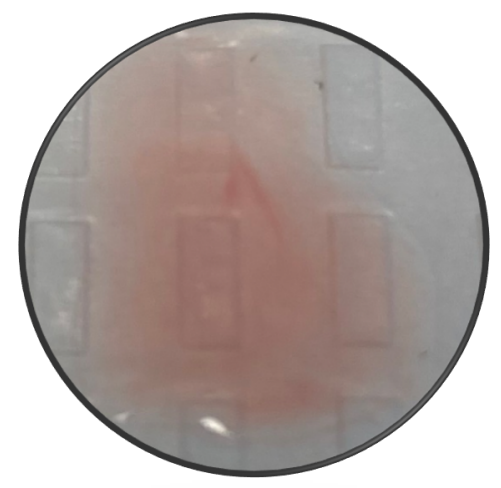

N-RBD-RBC

SARS-CoV2- plasma

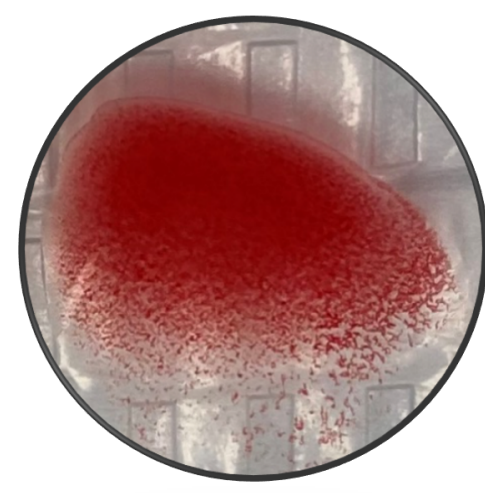

S-RBD-RBC SARS-CoV2+ plasma



N-RBD-RBC SARS-CoV2+ plasma

Figure S2. SARS-CoV2 antibody testing based on RBC agglutination.

Red blood cells (RBC, group O; R2R2) carrying the D antigen were labelled with anti$D \lg G$ conjugated to recombinant S-RBD or N-RBD through streptavidin-biotin (i.e., IgG-streptavidin conjugated to biotin-RBD). (A) S-RBD labeled RBCs were mixed with either SARS-CoV-2- (NAAT) or SARS-CoV2+ plasma (right). (B) N-RBD labeled RBCs were mixed with either SARS-CoV2- (left) or SARS-CoV2 ${ }^{+}$plasma (right). Images shown were taken after 1 min incubation at room temperature. 
medRxiv preprint doi: https://doi.org/10.1101/2020.11.30.20241208; this version posted December 2, 2020. The copyright holder for this preprint (which was not certified by peer review) is the author/funder, who has granted medRxiv a license to display the preprint in perpetuity.

All rights reserved. No reuse allowed without permission.

\section{Esmail et al.}

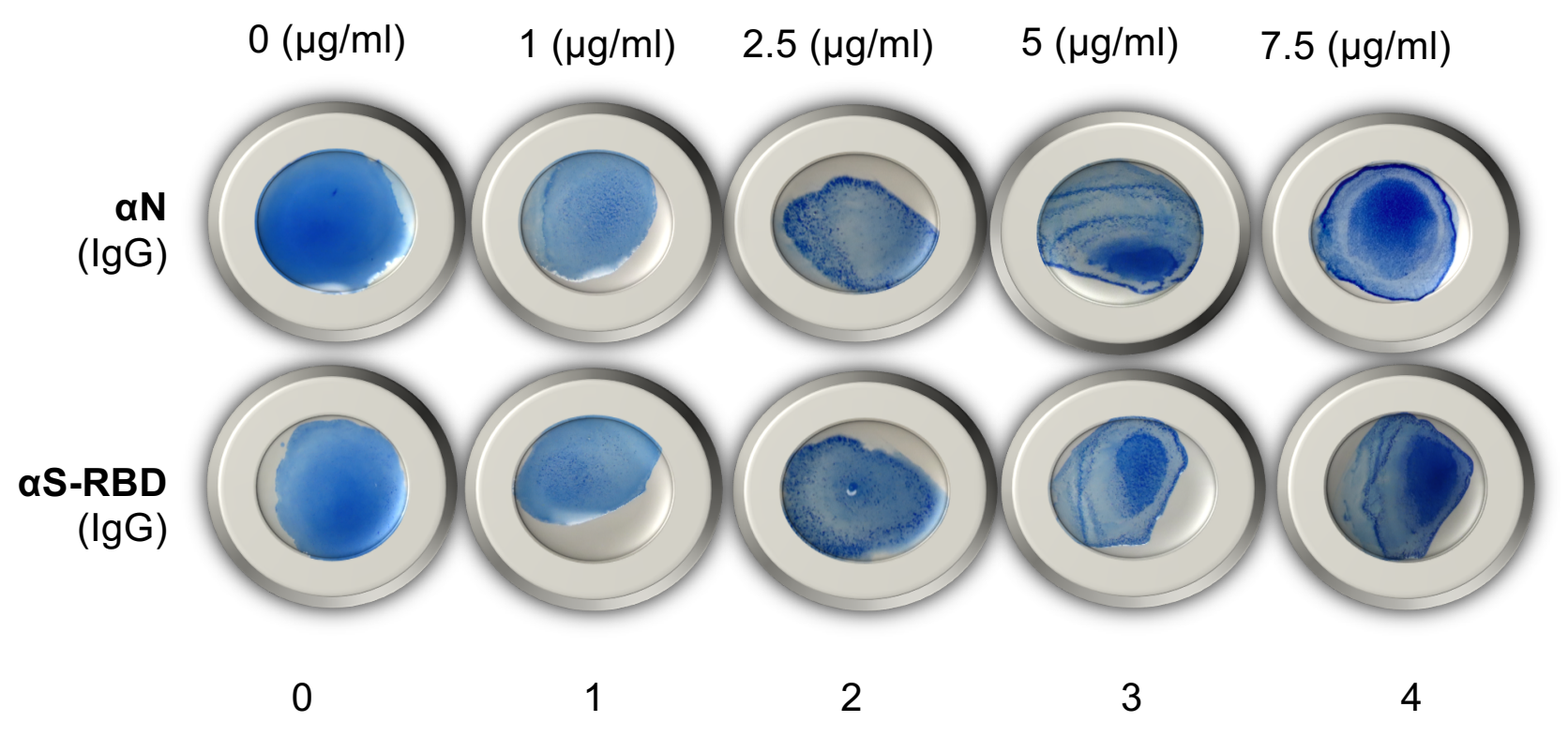

Agglutination Score

Figure S3. Agglutination of blue latex particles in response to different concentrations of antibody (IgG) against the nucleocapsid $(\alpha \mathrm{N})$ or S-RBD $(\alpha \mathrm{S}$ RBD). Anti-S-RBD (monoclonal, NBP2-90980) was obtained from Novus Biologicals; Anti-Nucleocapsid (polyclonal, PA5-81794) was from ThermoFisher Scientific. 
medRxiv preprint doi: https://doi.org/10.1101/2020.11.30.20241208; this version posted December 2, 2020. The copyright holder for this preprint (which was not certified by peer review) is the author/funder, who has granted medRxiv a license to display the preprint in perpetuity.

All rights reserved. No reuse allowed without permission.

\section{Esmail et al.}

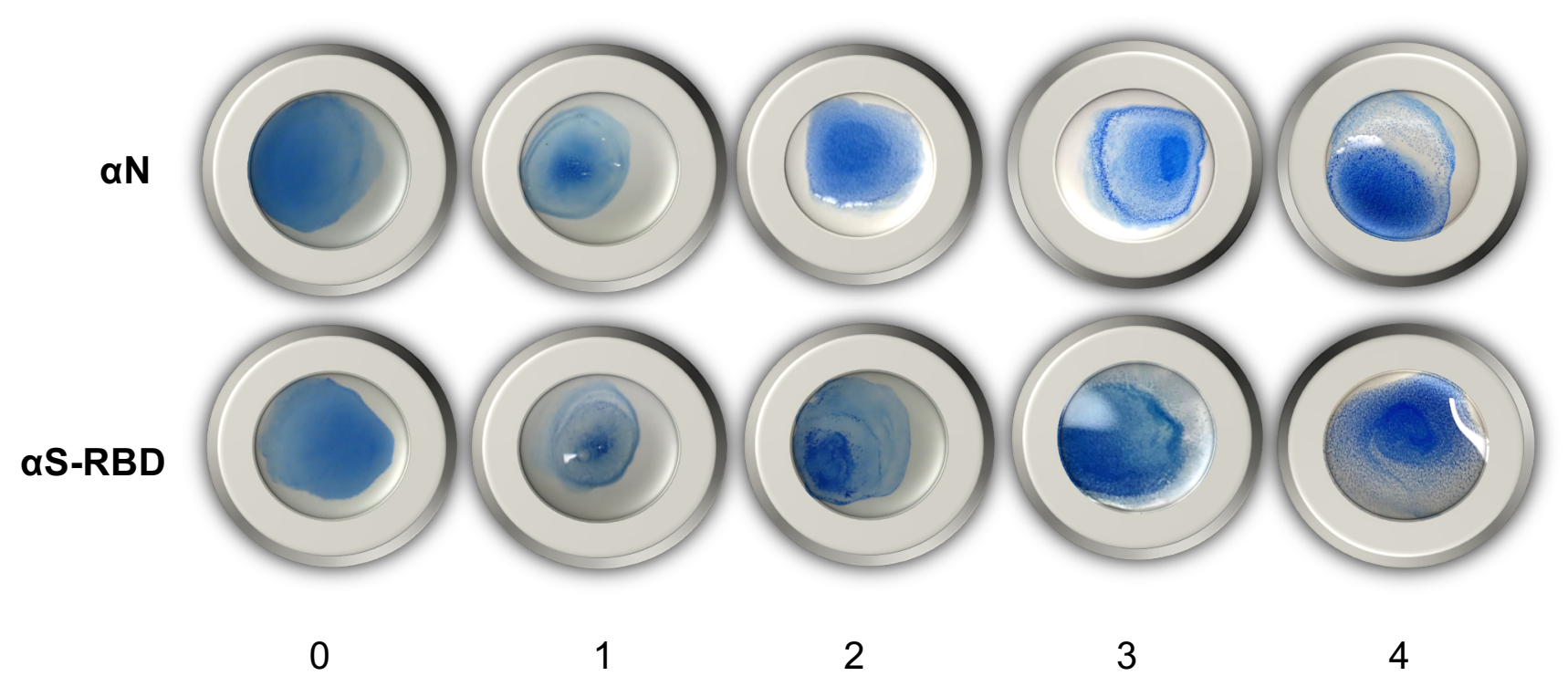

Agglutination Score

Figure S4. Representative images of agglutination induced by plasma with different agglutination scores. Shown are five samples with distinct agglutination scores (0-4) in the nucleocapsid $(\alpha \mathrm{N})$ (upper row) or the S-RBD antibody ( $\alpha \mathrm{S}-\mathrm{RBD})$ test (lower row). The scores were assigned as $4=75-100 \%$ agglutination; $3=50-75 \%$ agglutination; $2=25-50 \%$ agglutination; $1=5-25 \%$ agglutination; 0 (or negative) $\leq 5 \%$ agglutination. 
medRxiv preprint doi: https://doi.org/10.1101/2020.11.30.20241208; this version posted December 2, 2020. The copyright holder for this preprint (which was not certified by peer review) is the author/funder, who has granted medRxiv a license to display the preprint in perpetuity.

\section{Esmail et al.}
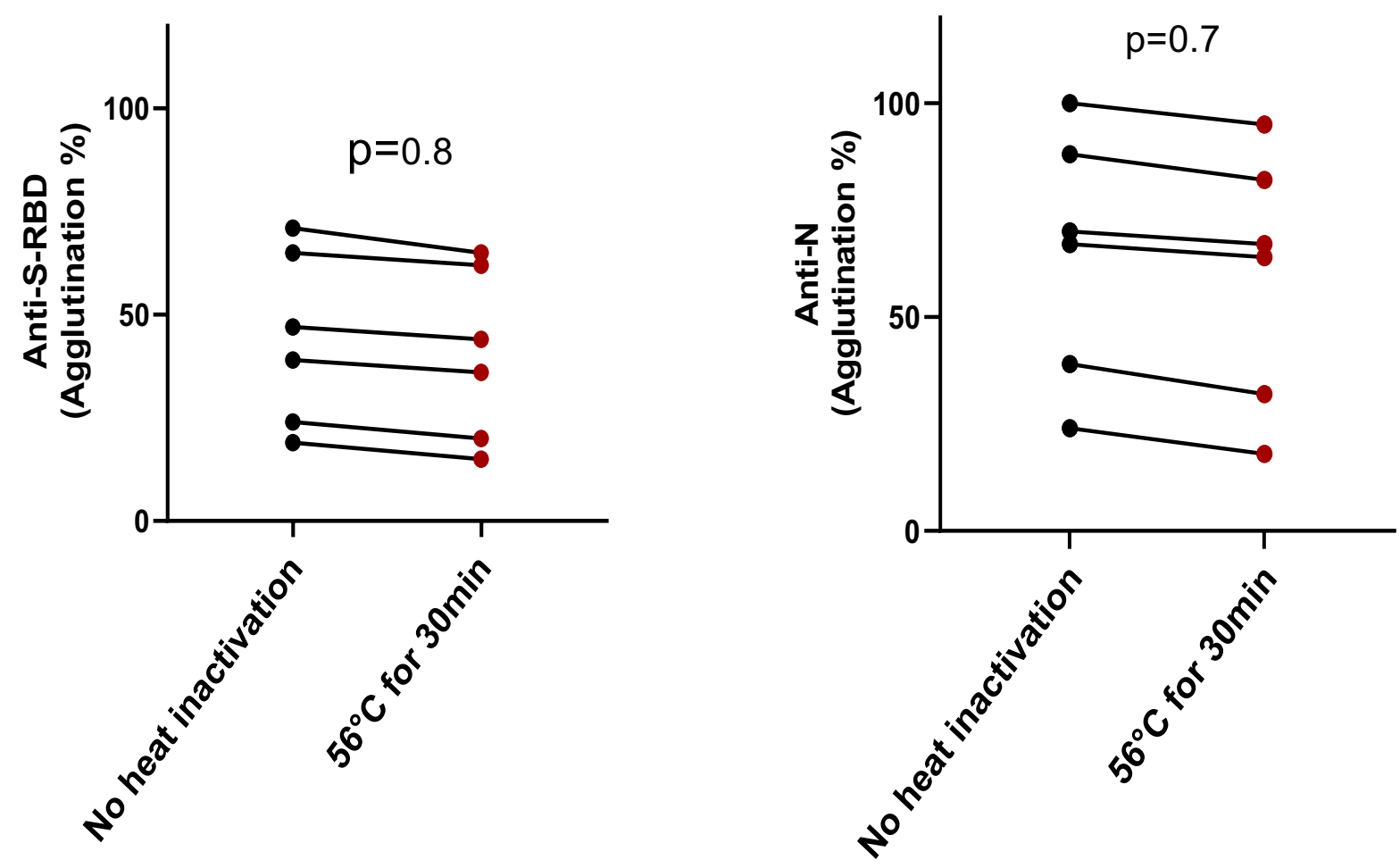

Figure S5. Heat inactivation of plasma did not affect antibody induced agglutination. Shown are agglutination percentages between samples without or with heat-inactivation in the anti-S-RBD (left) or anti-N (right) agglutination assay. p-values calculated from paired two tailed t-test (no assumption of equal variance, $n=6$ ). 